\title{
ANALISIS KETERAMPILAN PROSES SAINS PADA PELAKSANAAN PRAKTIKUM FISIKA DI SMAN 9 MAKASSAR
}

\author{
* Frafti Rejeki S \\ Universitas Negeri Makassar \\ fraftirejeki14@gmail.com
}

Usman

Universitas Negeri Makassar usman@unm.ac.id

Aisyah Azis

Universitas Negeri Makassar aisyahazis@unm.ac.id

*koresponden author
Abstrak - Penelitian ini bertujuan untuk mengetahui gambaran keterampilan proses sains (KPS) pada pelaksanaan praktikum fisika peserta didik di SMAN 9 Makassar. Variabel dalam penelitian ini adalah keterampilan proses sains dengan lima indikator yang akan diukur yaitu mengamati, menyusun hipotesis, merencanakan percobaan, menginterpretasi data dan mengomunikasikan. Sampel penelitian adalah peserta didik kelas X MIA 9 yang berjumlah 23 orang. Data hasil penelitian diperoleh dengan melakukan tes kinerja pelaksanaan praktikum fisika materi getaran harmonis sederhana kemudian memberikan tes tertulis dalam bentuk uraian. Teknik analisis data yaitu analisis deskriptif dengan menggunakan persentase skor. Berdasarkan hasil analisis data tes tertulis diperoleh bahwa rata-rata perolehan skor keterampilan proses sains peserta didik termasuk dalam kategori tinggi dengan persentase sebesar $71.56 \%$. Hasil tersebut diperkuat dengan hasil analisis data tes kinerja keterampilan proses sains peserta didik pada pelaksanaan praktikum fisika yang juga termasuk dalam kategori tinggi dengan persentase sebesar $61.30 \%$. Oleh karena itu dapat disimpulkan bahwa peserta didik sudah mampu menerapkan keterampilan proses sains pada pelaksanaan praktikum fisika.

Kata Kunci : Keterampilan, sains, praktikum, fisika, proses.

\begin{abstract}
This study aimed to know the students' science process skill (SPS) in physics experiment at SMAN 9 Makassar. The variable of this study was science process skill that consisted of five Indicators that were observing, hypothezing, planning an experiment, data interpreting, and communicating. The sample in this study was 23 students at class X MIA 9. Data of research got by observation while the students experimenting simple harmonic motion then doing the written test by essay questions. The data were analyzed descriptively using percentages. Based on the data analysis and discussion, it's showed that the student's science process skill in physics experiment based on written test was good with $71.56 \%$ average score. In addition the observation result showed the same result with $61.30 \%$ average score. So it was concluded that implementation of students' science process skill in physics experiment at SMAN 9 Makassar overall was good.
\end{abstract}

Keywords : Skill, Science, Process, Physics, Experiment 


\section{A. PENDAHULUAN}

Pembelajaran sains khususnya fisika merupakan kombinasi dua unsur yaitu proses dan produk yang tidak terpisahkan. Pembelajaran sains sebagai proses meliputi keterampilan proses dan sikap ilmiah yang diperlukan untuk memperoleh dan mengembangkan pengetahuan, sedangkan sains sebagai produk berupa kumpulan pengetahuan yang meliputi fakta, konsep, prinsip, teori dan hukum. Dengan demikian, pada hakikatnya sains merupakan ilmu pengetahuan tentang gejala alam berupa fakta, konsep, prinsip dan hukum yang teruji kebenarannya dan melalui suatu rangkaian kegiatan dalam metode ilmiah (Zubaidah, dkk., 2017).

Kurikulum 2013 menekankan pada penggunaan pendekatan saintifik (scientific approach) yang sejalan dengan metode ilmiah dalam pembelajaran sains. Proses pembelajaran dengan pendekatan saintifik terdiri atas lima pengalaman belajar yaitu mengamati, menanya, mengumpulkan informasi, mengasosiasi, dan mengomunikasikan. Prosedur ilmiah tersebut melatih peserta didik untuk menggunakan keterampilan proses sains (KPS) dalam kegiatan belajarnya. KPS sangat penting untuk pembelajaran sains yang bermakna karena dapat mendorong peserta didik untuk menerapkannya dalam kehidupan sehari-hari sehingga peserta didik harus mampu menemukan, menginterpretasi dan mencari bukti untuk setiap kondisi berbeda yang dihadapi (Karamostafaoglu, 2011).

Kurikulum 2013 menjelaskan bahwa penilaian kinerja peserta didik dalam proses pembelajaran berhubungan dengan kemampuan berpikir mereka. Kemampuan berpikir peserta didik untuk membangun konsep baru dalam pembelajaran sains dapat dilatih melalui pengembangan keterampilan proses sains. The American association for the advancement of Science (AAAS) mengatakan bahwa KPS sangat sesuai untuk pembelajaran sains, dan pembelajaran sains harus diarahkan pada pembelajran yang membuat peserta didik lebih aktif, memberikan mereka pengalaman langsung, dan melatih kemampuan berpikir mereka (Ratnasari, dkk. 2018).

Penerapan kurikulum 2013 di SMAN 9 Makassar telah berjalan dengan baik. Idealnya, pada pelaksanaan pembelajaran fisika dengan pendekatan saintifik melibatkan keaktifan peserta didik dan melibatkan guru sebagai fasilitator dan mitra belajarnya. Namun dalam proses pembelajaran fisika, peserta didik masih monoton pada penjelasan guru di kelas dan kurang termotivasi untuk membaca buku dan dan sumber belajar lain terkait materi yang dipelajari. Hal tersebut mengurangi kebermaknaan pembelajaran sains yang bukan hanya mencari tahu dan memahami fakta, konsep, prinsip dan hukum tetapi juga berupa penemuan.

Selain itu fasilitas dan sumber belajar yang menunjang pembelajaran seperti laboratorium fisika masih kurang optimal dalam pemberdayaannya. Cukup banyak alat dan bahan praktikum yang tidak tersedia maupun rusak. Hal ini menghambat jalannya proses praktikum yang dapat berujung pada kurangnya pengalaman langsung peserta didik untuk mengembangkan keterampilan proses yang dimiliki. Berdasarkan hal tersebut jelas bahwa, ilmu pengetahuan alam khususnya fisika bukan hanya produk tetapi juga proses. 
Keberhasilan suatu proses yang dicapai dapat diukur dan dievaluasi melalui tes hasil belajar peserta didik sehingga tingkat keberhasilan belajar akan diketahui. Menurut Harlen (1999), KPS tanpa penilaian akan membuat pembelajaran tidak berarti. KPS juga harus diterapkan pada bidang yang lainnya selain sains karena inti dari pembelajaran adalah pemahaman baik dalam pendidikan formal maupun kehidupan sehari-hari. Oleh karena itu penilaian KPS menjadi penting dilakukan.

\section{B. METODE}

Penelitian ini merupakan penelitian kualitatif, dimana data yang diperoleh dikategorikan secara deskriptif. Penelitian dilaksanakan pada semester genap tahun pelajaran 2018/2019 di SMA Negeri 9 Makassar, Jalan Karunrung Raya No. 37, Kecamatan Rappocini, Kota Makassar. Sampel dalam penelitian ini adalah 23 orang peserta didik kelas X MIA 9.

Variabel penelitian ini adalah keterampilan proses sains. Definisi keterampilan proses sains ialah ialah perolehan skor keterampilan proses sains peserta didik dalam pelaksanaan praktikum fisika yang diukur dari lima indikator, yaitu mengamati, menyusun hipotesis, merencanakan percobaan, menginterpretasi data, dan mengomunikasikan. Instrumen yang digunakan adalah lembar tes kinerja dan instrument tes yang terdiri dari 13 soal uraian. Teknik pengumpulan data yang digunakan adalah penilaian kinerja praktikum dan tes tertulis. Teknik analisis data yang digunakan dalam penelitian ini adalah analisis data secara deskriptif.

\section{HASIL DAN PEMBAHASAN}

Analisis keterampilan proses sains peserta didik kelas X MIA 9 di SMAN 9 Makassar dimulai dengan penilaian kinerja praktikum fisika pada saat pelaksanaan praktikum dan melalui LKPD kemudian dilanjutkan dengan memberikan tes tertulis dalam bentuk soal uraian. Skor peserta didik diperoleh berdasarkan rubrik penilaian masing-masing instrumen yang telah ditetapkan sebelumnya.

a. Hasil analisis data tes kinerja praktikum

Tabel 1. Perolehan Skor Keterampilan Proses Sains berdasarakan Hasil Analisis Data Tes Kinerja Praktikum Peserta Didik di SMAN 9 Makassar.

\begin{tabular}{cccc}
$\begin{array}{c}\text { Interval } \\
\text { Skor }\end{array}$ & Kategori & Frekuensi & $\begin{array}{c}\text { Persentase } \\
(\%)\end{array}$ \\
\hline $0-4$ & Sangat & 0 & 0 \\
& Rendah & & \\
$5-8$ & Rendah & 0 & 0 \\
$9-12$ & Cukup & 10 & 43.47 \\
$13-16$ & Tinggi & 13 & 56.52 \\
$17-20$ & Sangat & 0 & 0 \\
& Tinggi & & \\
\hline Jumlah & 23 & 100 \\
\hline
\end{tabular}


Tabel 2. Gambaran Keterampilan Proses Sains Hasil Tes Kinerja Peserta Didik di SMAN 9 Makassar.

\begin{tabular}{|c|c|c|}
\hline Indikator KPS & $\begin{array}{c}\text { Rata- } \\
\text { rata }(\%)\end{array}$ & Kategori \\
\hline Mengamati & 75.00 & Tinggi \\
\hline Menyusun Hipotesis & 41.30 & Cukup \\
\hline $\begin{array}{l}\text { Merencanakan } \\
\text { Percobaan }\end{array}$ & 68.48 & Tinggi \\
\hline Menginterpretasi data & 56.52 & Cukup \\
\hline Mengomunikasikan & 65.22 & Tinggi \\
\hline Rata-rata Keseluruhan & 61.30 & Tinggi \\
\hline
\end{tabular}

b. Hasil analisis data tes tertulis

Tabel 3. Perolehan Skor Tes Keterampilan Proses Sains Peserta Didik Hasil Tes Tertulis di SMAN 9 Makassar

\begin{tabular}{|c|c|c|c|}
\hline $\begin{array}{c}\text { Interval } \\
\text { Skor }\end{array}$ & Kategori & Frekuensi & $\begin{array}{c}\text { Persentase } \\
(\%)\end{array}$ \\
\hline $0-10$ & $\begin{array}{l}\text { Sangat } \\
\text { Rendah }\end{array}$ & 0 & 0 \\
\hline $11-21$ & Rendah & 0 & 0 \\
\hline $22-32$ & Cukup & 2 & 8.69 \\
\hline $33-43$ & Tinggi & 19 & 82.61 \\
\hline $44-54$ & $\begin{array}{l}\text { Sangat } \\
\text { Tinggi }\end{array}$ & 2 & 8.69 \\
\hline \multicolumn{2}{|c|}{ Jumlah } & 23 & 100 \\
\hline
\end{tabular}

Tabel 4. Gambaran Keterampilan Proses Sains Peserta Didik Hasil Tes Tertulis di SMAN 9 Makassar

\begin{tabular}{lcc}
\multicolumn{1}{c}{ Indikator KPS } & $\begin{array}{c}\text { Rata-rata } \\
(\boldsymbol{\%})\end{array}$ & Kategori \\
\hline Menyusun Hipotesis & 61.23 & Tinggi \\
Menginterpretasi data & 77.72 & Tinggi \\
Mengomunikasikan & 75.72 & Tinggi \\
\hline \multicolumn{1}{c}{ Rata-rata Keseluruhan } & 71.56 & Tinggi \\
\hline
\end{tabular}

Berdasarkan hasil analisis data tes kinerja praktikum dan tes tertulis keterampilan proses sians peserta didik di SMAN 9 Makassar diperoleh bahwa rata-rata skor perolehan keterampilan proses sains peserta didik berada dalam kategori tinggi. Berdasarkan frekuensi dan persentase kategori skor perolehan KPS hasil tes kinerja praktikum peserta didik pada tabel 1, terlihat bahwa sebanyak 13 orang peserta didik yang memiliki keterampilan proses sains yang tinggi dengan persentase $56.52 \%$. Perolehan tertinggi peserta didik ada pada indikator mengamati. Hasil ini menunjukkan bahwa pembelajaran melalui metode praktikum dapat meningkatkan keterampilan mengamati peserta didik dengan baik karena peserta didik benar-benar dihadapkan pada objek nyata yang 
mengoptimalkan penggunaan pancaindera. Hal ini sejalan dengan penelitian yang dilakukan oleh Nurshinta (2018) yang memperoleh hasil yang sama.

Adapun frekuensi dan persentase kategori skor perolehan KPS hasil tes tertulis peserta didik pada tabel 3, terlihat bahwa sebanyak 19 orang peserta didik yang memiliki keterampilan proses sains yang tinggi dengan persentase sebesar $82.61 \%$. Perolehan tertinggi peserta didik ada pada indikator mengomunikasikan yang menunjukkan bahwa peserta didik sudah mampu mengomunikasikan data hasil penelitian dalam bentuk grafik ataupun tabel. Perolehan terendah pada tes kinerja dan tertulis keduanya ada pada indikator menyusun hipotesis. Hasil ini menunjukkan bahwa peserta didik masih kesulitan dalam berpikir secara hipotesis dalam pelaksanaan praktikum dan pemecahan masalah.

Hasil analisis tersebut membuktikan bahwa perolehan persentase skor KPS yang tinggi pada proses pembelajaran dapat mempengaruhi hasil tes peserta didik. Perolehan skor pada hasil analisis data tes kinerja praktikum berada dalam kategori tinggi begitupun dengan hasil analisis data tes tertulis. Ketika peserta didik sering menerapkan keterampilan proses sains dengan tepat, mereka akan menguasai keterampilan proses yang berakibat meningkatnya hasil tes tertulis mereka. Pengetahuan dapat diukur melalui tes tertulis KPS dan keterampilan dapat diukur melalui tes kinerja/pengamatan dari kegiatan KPS. Hasil ini menunjukkan bahwa penilaian KPS lebih baik menggunakan berbagai macam metode untuk memaksimalkan perbaikan KPS peserta didik (Azizah, dkk. 2018).

\section{SIMPULAN}

Berdasarkan hasil analisis data dan pembahasan dari penelitian yang telah dilaksanakan maka dapat disimpulkan bahwa keterampilan proses sains peserta didik kelas X MIA 9 di SMAN 9 Makassar termasuk dalam kategori tinggi. Hasil tes kinerja peserta didik menunjukkan bahwa keterampilan mengamati, merencanakan percobaan, dan mengomunikasikan berada pada kategori tinggi sedangkan menyusun hipotesis dan menginterpretasi data berada dalam kategori cukup. Adapun hasil tes tertulis menunjukkan bahwa keterampilan menyusun hipotesis, menginterpretasi data, dan mengomunikasikan berada dalam kategori tinggi.

\section{DAFTAR RUJUKAN}

Azizah, K. N., Ibrahim, M., \& Widodo, W. (2018). Process Skill Assessment Instrument: Innovation to Measure Students' Learning Holistically. Journal of Physics: Conference Series (pp. 1-5). Indonesia: IOP Publishing.

Djamarah, S. B., \& Azwan, Z. (2010). Strategi Belajar Mengajar. Jakarta: Rineka Cipta.

Harlen, W. (1999). Purposes and Procedures for Assesing Science Process Skills. Assessment in Education, 6(1),129-144.

Karamostafaoglu, S. (2011). Improving The Science Process Skill Ability of Science Student Teacher Using I Diagrams. Eurasian Journal of Physics and Chemistry Education, 3(1), 26-38. 
Mundilarto. (2002). Kapita Selekta Pendidikan Fisika. Yogyakarta: Universitas Negeri Yogyakarta.

Nurshinta, E. (2018). Analisis Keterampilan Proses Sains (KPS) Siswa melalui Model Pembelajaran Problem Based Learning di SMAN 1 Labuanhaji. Banda Aceh: UIN Ar-Raniry.

Ozgelen, S. (2012). Students' Science Process Skills within a Cognitive Domain Framework. Eurasian Journal of Mathematics, Science and Technology Education, 8(4), 283-292.

Ratnasari, D., Sukarmin, Suparmi, \& Harjunowibowo, D. (2018). Analysis of Science Process Skill of Summative Test Items in Physics Physics of Grade X in Surakarta. Jurnal Pendidikan IPA Indonesia, 7(1),34-40.

Tawil, M., \& Liliasari. (2014). Keterampilan-Keterampilan Sains dan Implementasinya dalam Pembelajaran IPA. Makassar: Badan Penerbit UNM.

Zamista, A. A., \& Kaniawati, I. (2015). Pengembangan Tes Keterampilan Proses Sains Materi Fluida Statis Kelas X SMA/MA. Prosiding Seminar Nasional Fisika (E-Journal) SNF2015 (pp. 5-10). Jakarta: Universitas Negeri Jakarta.

Zubaidah, S., Mahanal, S., Yuliati, L., Dasna, I. W., Pangestuti, A. A., Puspitasari, D. R., . . . Sholihah, M. (2017). Buku Guru Ilmu Pengetahuan Alam. Jakarta: Kementrian Pendidikan dan Kebudayaan 